\title{
Physical-Biological Coupling in Southern Lake Michigan: Influence of Episodic Sediment Resuspension on Phytoplankton
}

\author{
David F. Millie ${ }^{1, *}$, Gary L. Fahnenstiel ${ }^{2}$, Steven E. Lohrenz ${ }^{3}$, Hunter J. Carrick ${ }^{4}$, Thomas \\ H. Johengen ${ }^{5}$ and Oscar M.E. Schofield ${ }^{6}$ \\ ${ }^{1}$ Florida Institute of Oceanography, University of South Florida, 830 First Street, S., Saint Petersburg, Florida \\ 33701, USA; ${ }^{2}$ Lake Michigan Field Station, Great Lakes Environmental Research Laboratory, National \\ Oceanic and Atmospheric Administration, 1431 Beach Street, Muskegon, Michigan 49441, USA; ${ }^{3}$ Department \\ of Marine Science, University of Southern Mississippi, Stennis Space Center, Mississippi 39529, USA; \\ ${ }^{4}$ School of Forest Resources- Fisheries and Wildlife, Pennsylvania State University, University Park, \\ Pennsylvania 16802, USA; ${ }^{5}$ Cooperative Institute of Limnology and Ecosystems Research, University of \\ Michigan, Ann Arbor, Michigan 48109, USA; ${ }^{6}$ Institute of Marine and Coastal Sciences, Rutgers University, \\ 71 Dudley Road, New Brunswick, NJ 08901, USA; *Author for correspondence (Fax: (727) 550-4222; e-mail: \\ david.millie@fwc.state.fl.us)
}

Received 11 March 2003; accepted in revised form 15 August 2003

Key words: Coastal resuspension, Diatoms, Great Lakes, Growth, Microalgae, Photosynthesis

\begin{abstract}
The influence of episodic, sediment resuspension on phytoplankton abundance/volume and composition, the photosynthetic maximum rate $\left(\mathrm{P}_{\max }^{\mathrm{B}}\right)$ and efficiency $\left(\alpha^{\mathrm{B}}\right)$, and chlorophyll-specific growth $\left(\mu_{\mathrm{Chl}}\right)$ was evaluated during the spring isothermal period in southern Lake Michigan (Laurentian Great Lakes, USA). Resuspension altered the nutrient and light climate of nearshore waters; light attenuation $\left(\mathrm{K}_{\mathrm{d}}\right)$ and phosphorus concentrations corresponded ( $\mathrm{p} \leq 0.0001$ and $\mathrm{p} \leq 0.001$, respectively) with concentrations of suspended particulate matter (SPM). Phytoplankton cell volume and diatom cell abundance and volume were not associated with SPM concentrations $(\mathrm{p}>0.05)$. Diatom composition displayed spatial dissimilarities corresponding with resuspension ( $\mathrm{p}$ $\leq$ 0.001); small centric diatoms exhibiting meroplanktonic life histories and pennate diatoms considered benthic in origin were most abundant within SPM-impacted, nearshore waters whereas taxa typically comprising assemblages in optically-clear, offshore waters and the basin-wide, spring bloom were not. Values of $\mathrm{P}_{\max }^{\mathrm{B}}$ and $\alpha^{\mathrm{B}}$ corresponded ( $\mathrm{p} \leq$ 0.0001) with both $\mathrm{K}_{\mathrm{d}}$ coefficients and SPM concentrations, potentially reflecting increased light harvesting/utilization within impacted assemblages. However, integral production was inversely associated with $\mathrm{K}_{\mathrm{d}}$ coefficients and SPM concentrations $(\mathrm{p}<0.0001)$ and photosynthesis was light-limited (or nearly so) for most assemblages. Although $\mu_{\mathrm{Chl}}$ values corresponded with $\mathrm{K}_{\mathrm{d}}$ coefficients $(\mathrm{p} \leq 0.05$ ), values were quite low $\left(\overline{\mathrm{x}} \pm\right.$ S.E., $\left.0.10 \pm 0.004 \mathrm{~d}^{-1}\right)$ throughout the study. Most likely, distinct rate processes between SPM- and nonimpacted assemblages reflected short-term compositional (and corresponding physiological) variations due to infusion of meroplankton and/or tributary-derived phytoplankton. Overall, resuspension appears to have little, if any, long-term impact upon the structure and function of the lake's phytoplankton.
\end{abstract}




\section{Introduction}

Coastal waters exhibit variable hydrodynamic conditions that dramatically influence phytoplankton. Turbulent mixing suspends sediments and chromophoric dissolved organic material throughout the water column, while also introducing benthic-derived nutrients (Cloern 1987; Cotner et al. 2000). If mixing is prolonged, viable benthic cells and/or dormant resting spores/cysts resuspended from the sediments (i.e., meroplankton) may significantly alter phytoplankton composition and biomass (Carrick et al. 1993; Schelske et al. 1995). Advection, circulation, and upwelling processes may transport assemblages and particulate matter throughout nearshore waters (Lohrenz et al. 1988; Demers et al. 1989; Claustre et al. 1994). Inflows from tributaries also contribute significant sediment, nutrient, and biological 'loading' into littoral waters (Klarer and Millie 1989; O’Donohue and Dennison 1997).

The Laurentian Great Lakes (USA and Canada) constitute the largest system of fresh, surface water on earth (containing ca. eighteen percent of the world supply; US EPA and Gov. Can. 1995); as such, they are an invaluable natural resource and impact global climatology and carbon cycling. During isothermal periods, intense vertical mixing and turbulence characterize the water column of Lake Michigan, the second largest of the Great Lakes by volume (ca. 4900 $\mathrm{km}^{-3}$; US EPA and Gov. Can. 1995). Resuspension of silt and clay-like particles, first described by Mortimer (1988) from satellite imagery reflectance, is now recognized as an annually recurrent coastal feature within lake's southern basin during the spring holomixis (see Figure 1B). Resuspension is initiated within near-shore waters by major, late-winter storms with strong northerly winds. Resuspension events often are expansive and of variable duration and intensity; the events in 1996 and 1998 were particularly intense and extended over $300 \mathrm{~km}$ of coastline, while persisting for over a month (Eadie et al. 1996; Eadie et al. 2002; Schwab et al. 2000).

The linkages between such synoptic-scale, physical forcing and phytoplankton within coastal waters, including those of the Great Lakes, are poorly understood. Moreover, interpreting the structure and function of coastal Lake Michigan phytoplankton requires a comprehension of the natural variability of phytoplankton composition and physiological rate processes in relation to both meteorologically-driven holomixis and episodic sediment resuspension. Pro- longed sediment resuspension increases near-shore nutrient availability and light attenuation (Cotner et al. 2000; Millie et al. 2002a) and potentially may alleviate phosphorus limitation and/or invoke light limitation within impacted assemblages. Following resuspension, particulate matter is transported offshore through wind-driven circulation patterns (Schwab et al. 2000; Eadie et al. 2002) and may provide a dispersal mechanism for the lake's nearshore assemblages. Because resuspension often temporally coincides with the initiation of the spring phytoplankton bloom (a basin-wide event contributing up to half of the lake's total annual primary production; Fahnenstiel and Scavia 1987a; Brooks and Eddington 1994), phytoplankton abundance and production during this period may be attributable, in part, to infusion of resuspension-derived meroplankton and/or nutrients into the near-shore water column.

We hypothesized that episodic resuspension would provide for dissimilar physical and chemical properties between sediment-impacted and adjacent waters and that these dissimilarities, in conjunction with meroplankton resuspension and subsequent offshore transport, impart variability in both phytoplankton abundance and composition throughout coastal waters. Such alterations in assemblage distributions and composition also were postulated to result in disparities among assemblage physiological rate processes and production along nearshore-offshore gradients. Here, phytoplankton biomass, growth, and photosynthesis are characterized during the spring isothermalmixing period within southern Lake Michigan.

\section{Methods}

Synoptic survey cruises were conducted within southeastern Lake Michigan onboard the R.V. Laurentian during the spring isothermal periods of 1998 , 1999, and 2000. Depending upon the year and spatial distribution of the resuspension event, sampling stations were established within sediment-impacted and adjacent waters (ranging from 10 to $110 \mathrm{~m}$ maximum depth) along the Muskegon, St. Joseph, New Buffalo, Cook and/or Gary transects (Figure 1A). At each station, photosynthetic active radiation (PAR; 400 to 700 $\mathrm{nm})$ profiles of the water column were collected using a Sea-Bird CTD package equipped with a Bio-spherical Instruments down-welling PAR sensor. Modified Niskin bottles (all rubber parts were replaced with Teflon-coated or silicone; Fahnenstiel et 
A)

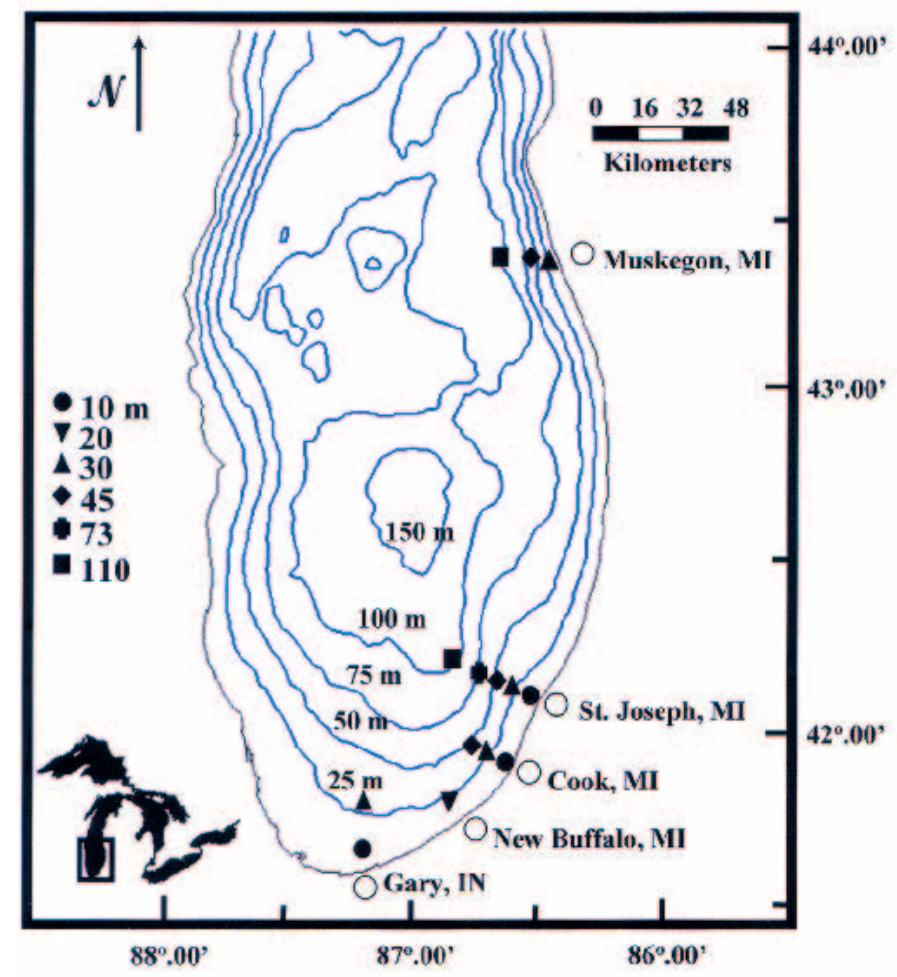

B)

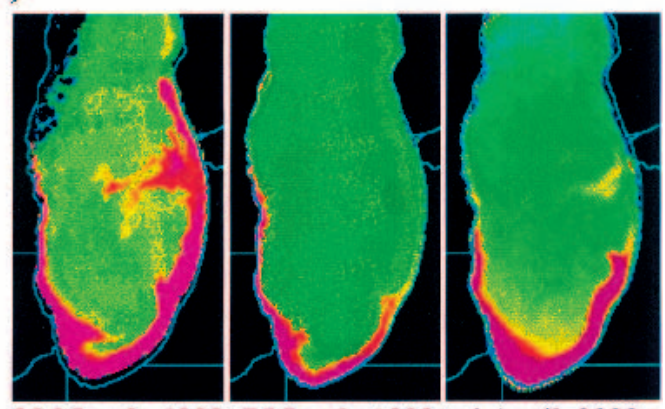

23 March, 19987 March, $1999 \quad 4$ April, 2000

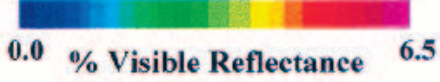

C)

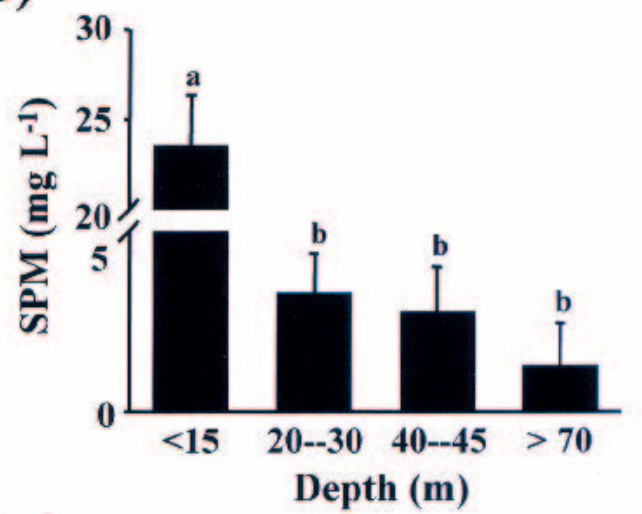

Figure 1. (A) Location of sampling stations along the Cook, Gary, Muskegon, New Buffalo, and St. Joseph transects. Inset Figure places study area relative to the Laurentian Great Lakes. (B) Reflectance imagery of southern Lake Michigan derived from Band 1-2 data acquired by the Advanced Very High Resolution Radiometer flown onboard the NOAA-14 polar-orbiting environmental satellite. Red/yellow colors depict suspended particulate matter (SPM) at the maximum spatial extent of resuspension during each year of the study. (C) SPM concentrations as a function of water-column depth for 1998 to 2000. Data are means \pm standard error (total $\mathrm{n}=36$ ). Means with different letters are significantly different $(\mathrm{p} \leq 0.05)$.

al. 2002) were cast to selected depths to collect water for abiotic and biotic characterization (see below).

\section{Physical and chemical parameters}

Light parameters were determined using calculations from Wetzel (2001) and Fahnenstiel et al. (2000). Vertical extinction coefficients $\left(\mathrm{K}_{\mathrm{d}}\right)$ were calculated from PAR profiles. The euphotic depth $\left(\mathrm{Z}_{\mathrm{E}}\right)$ was assumed to equal the depth of $1 \%$ of surface irradiance $\left(\mathrm{I}_{0}\right)$ and determined using $\mathrm{K}_{\mathrm{d}}$ values. Depth-specific irradiance $\left(\mathrm{I}_{\mathrm{Z}}\right)$ was calculated as:

$$
\mathrm{I}_{\mathrm{Z}}=\mathrm{I}_{0} \mathrm{e}^{-\mathrm{kZ}}
$$

where $\mathrm{Z}$ is depth. Mean irradiance within the mixed layer $\left(\overline{\mathrm{I}}_{\mathrm{Zm}}\right)$ was calculated by integrating Equation 1 over the mixed layer, or:

(2)

$$
\overline{\mathrm{I}}_{\mathrm{Zm}}=\left(\mathrm{I}_{0} / \mathrm{kZ} \mathrm{m}_{\mathrm{m}}\right)\left(1-\mathrm{e}^{-\mathrm{kZm}}\right)
$$

where $\mathrm{Z}_{\mathrm{m}}$ is the depth of the mixed layer. During isothermal mixing within Lake Michigan, the mixing depth equals the water-column depth (therefore, $\overline{\mathrm{I}}_{\mathrm{Zm}}=\overline{\mathrm{I}}_{\mathrm{wcd}}$; Fahnenstiel et al. 2000).

Concentrations of suspended particulate matter (SPM) were determined gravimetrically after drawing aliquots of water under low vacuum onto pre-rinsed, tared Whatman GF/F and/or Poretics 0.4- $\mu \mathrm{m}$ polycarbonate filters. Dissolved nutrient concentrations were 
determined from filtrates after drawing aliquots of water under low vacuum through $0.2-\mu \mathrm{m}$ nylon filters. Total-, total dissolved-, particulate-, and soluble reactive-phosphorus (TP, TDP, $\mathrm{PP}$, and SRP), nitratenitrogen $\left(\mathrm{NO}_{3}\right)$, ammonium $\left(\mathrm{NH}_{4}\right)$, total and particulate silicate (TSi, PSi) and chloride $(\mathrm{Cl})$ concentrations were measured using standard colorimetric procedures on an Auto Analyzer II (detailed in Davis and Simmons, 1979). Aliquots for TP and TDP initially were stored in acid-cleaned Pyrex test tubes at $5{ }^{\circ} \mathrm{C}$, later digested in an autoclave (after addition of potassium persulfate), and measured as SRP (Menzel and Corwin, 1965). Particulate organic carbon (POC) and nitrogen (PON) concentrations were determined from whole-water samples using a Carlo-Erba Model $1110 \mathrm{CHN}$ elemental analyzer. Total $\mathrm{CO}_{2}$ concentration was determined from alkalinity and $\mathrm{pH}$ measurements (Vollenweider 1974).

\section{Biological variables}

Sub-surface phytoplankton (5 to $15 \mathrm{~m}$ depth) from sites representing both sediment-impacted and adjacent waters during 1998 and 1999 were preserved in amber bottles with Utermöhl's solution (Utermöhl 1958). Species compositions later were enumerated using standard microscopic techniques. Cell volumes were estimated by determining average cell dimensions and then applying these dimensions to appropriate geometric shapes. The cell volumes used here were from a compilation of values from previous studies within the Great Lakes (e.g., Fahnenstiel and Scavia 1987b; Fahnenstiel et al. 2000).

${ }^{14}$ Carbon-based photosynthetic measurements were derived from aliquots of water incubated within a photosynthetron, after the technique described by Fahnenstiel et al. (1995a, 2000) for Great Lakes assemblages. Whole-water chlorophyll (Chl) $a$ concentrations were determined fluorometrically (after Fahnenstiel et al. 2000). A photosynthesis-irradiance (P-I) plot for each incubation was constructed using photosynthetic rates, normalized to $\mathrm{Chl} a$, and incubation irradiances (ca. 1 to $1,800 \mu \mathrm{m} \mathrm{m}^{-2} \mathrm{~s}^{-1}$ ). From this plot, $\mathrm{P}_{\max }^{\mathrm{B}}$ (the maximum, light-saturated photosynthetic rate), $\alpha^{\mathrm{B}}$ (the efficiency, defined as the initial, light-limited slope of the P-I plot), and $\mathrm{I}_{\mathrm{k}}$ (the saturation irradiance, defined as the intercept between $\alpha^{\mathrm{B}}$ and $\mathrm{P}_{\max }^{\mathrm{B}}$ ) were calculated (after Fahnenstiel et al. 1989). The Great Lakes Production Model (GLPM) used $\mathrm{P}_{\max }^{\mathrm{B}}, \alpha^{\mathrm{B}}$, Chl $a$, and diel surface PAR to esti- mate in situ daily integral production (see Fahnenstiel et al. 1995a; Lang and Fahnenstiel 1996).

Growth rates $\left(\mu_{\mathrm{Chl}}\right)$ were determined from ${ }^{14}$ carbon uptake into $\mathrm{Chl} a$ within water incubated in a shipboard incubator, after the technique used by Fahnenstiel et al. (2000) for Great Lakes assemblages. A growth-irradiance (G-I) plot was constructed using growth rates and incubation irradiances (simulating irradiances and spectral qualities for the depths from which water was collected) from all experiments. From this plot, $\mu_{\max }$ (the maximum, light-saturated growth rate), $\alpha_{\mu}$ (the initial, light-limited slope of the G-I plot), and $I_{k, \mu}$ (the saturation irradiance, defined as the intercept between $\alpha_{\mu}$ and $\mu_{\max }$ ) were calculated (after Fahnenstiel et al. 1989; Fahnenstiel et al. 2000).

\section{Statistical analyses}

Principal Component Analysis (PCA), utilizing euclidean distances, characterized sampling sites in 1998 and 1999 with respect to $\mathrm{K}_{\mathrm{d}}$ coefficients and SPM and nutrient concentrations. Prior to PCA, pairwise scatter plots were constructed to illustrate symmetric distribution of/or linear relationships among variables (Clarke and Gorley 2001). An un-paired Ttest or ANOVA assessed differences among abiotic and biotic parameters among water-column depths and/or sampling years. A Tukey Test determined the significance between pairs of means within each ANOVA. Pearson Product Moment Correlation analyses determined the strength of associations between abiotic and biotic variables. Data were square rootor logarithmic-transformed prior to statistical analysis (where appropriate) to increase the variance and homogeneity of normalcy within data sets.

Similarity/dissimilarity in phytoplankton species composition was assessed by non-metric MultiDimensional Scaling (MDS; Clarke and Gorley 2001; Clarke and Warwick 2001). Briefly, Bray-Curtis similarity coefficients were computed between pairs of samples for each of the cell abundance and cell volume matrices. Coefficients within each matrix were assigned a rank order and ordination in two-dimensional space was constructed iteratively, such that the final relative distances between samples were in the same rank order as the relative coefficient dissimilarities (in this manner, samples placed close together represent comparable species composition whereas samples positioned far apart represent very different compositions). The similarity between abundance and volume rank matrices was compared by calculating a 
rank correlation coefficient $(\rho)$ between all elements of the matrices and then comparing this value to a frequency histogram created by randomly permuting samples and recalculating $\rho$. Because resuspension impacted all transects to varying degrees during 1998 and diatom Chl $a$ dominated surficial sediments (Millie et al. 2002a), diatom composition in 1998 was assessed independently by MDS. A one-way Analysis of Similarity (ANOSIM) assessed assemblage differences between sampling years and/or among station groups. A Similarity Percentage analysis (SIMPER) determined contributions for each species to the mean group dissimilarity. A forward/backward step-wise search analysis validated SIMPER results and identified subsets of taxa that best approximated the overall ordination (Spearman Rank Correlation $>0.95$ ).

\section{Results}

Resuspension occurred along the southern and southeastern coast of Lake Michigan during all spring isothermal periods. During 1998, resuspension extended along the lake's extreme southern portion to north of the Muskegon transect and a significant distance offshore. During 1999 and 2000, sediment resuspension only extended to north of the St. Joseph transect and occurred mostly nearshore (Figure 1B). Isothermal and/or near-isothermal profiles (ca. $1-5{ }^{\circ} \mathrm{C}$ ) indicated a holomictic water column during all cruise periods. SPM concentrations within near-surface waters during 1998 to 2000 were greatest at the most nearshore stations ( $\mathrm{p} \leq$ 0.0005; Figure 1C). Coefficients of $\mathrm{K}_{\mathrm{d}}$ and $\mathrm{Z}_{\mathrm{E}}$ values were positively and negatively associated ( $\mathrm{p} \leq 0.0001$, Figure 2A, Figure 2B) with SPM concentrations. The greatest variability among $\mathrm{K}_{\mathrm{d}}$ coefficients (0.13-2.64 $\left.\mathrm{m}^{-1}\right)$ and lowest observed $Z_{E}$ values (ca. 2-26 m) coincided with the maximum variability in sediment resuspension $(0.72-35.28 \mathrm{mg}$ $\mathrm{I}^{-1}$ ) during 1998. Maximum $\mathrm{K}_{\mathrm{d}}$ coefficients and minimum $\mathrm{Z}_{\mathrm{E}}$ values occurred in nearshore waters and decreased and increased, respectively, in offshore waters $\left(\mathrm{p} \leq 0.001\right.$; Figure 2C). Annual ratios of $\mathrm{Z}_{\mathrm{E}} \mathrm{S}_{\mathrm{d}}^{-1}$ were different $(\mathrm{p} \leq 0.001)$ and ranged from $0.31 \pm 0.05$ $0.6 \pm 0.08(0 \pm$ S.E. $)$, with the former value corresponding to 1998 when the expanse and intensity of resuspension was greatest.

Sampling stations differed with respect to physical and chemical parameters between 1998 and 1999 (Figure 3A). The initial two principal components of the PCA included descriptors indicative of sediment
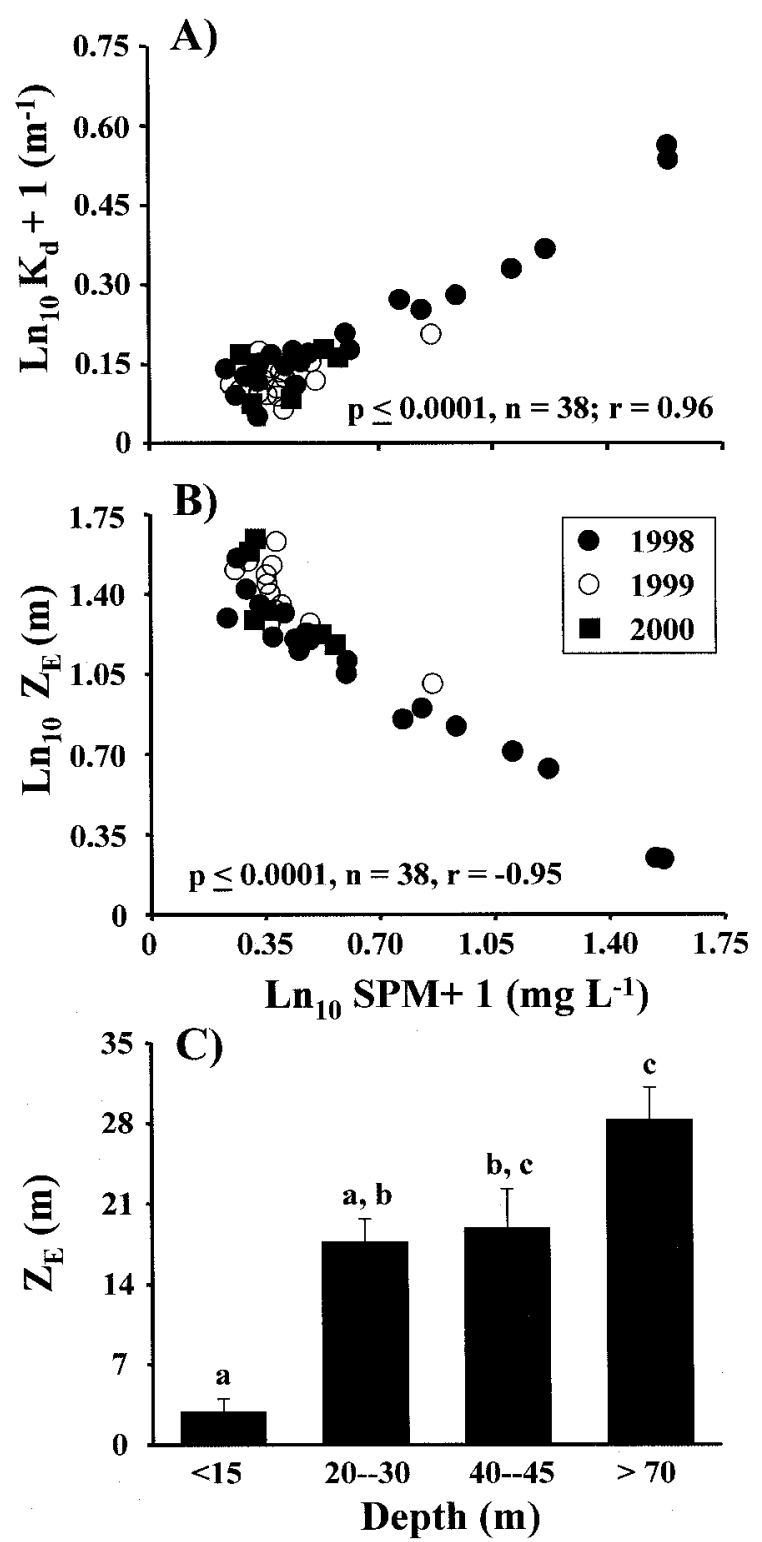

Figure 2. Relationships of $(A)$ attenuation coefficients $\left(\mathrm{K}_{\mathrm{d}}\right)$ and $(\mathrm{B})$ euphotic depth $\left(\mathrm{Z}_{\mathrm{E}}\right)$ with water-column concentrations of suspended particulate matter $(S P M)$. Corresponding statistical information represents analyses performed on the entire data set. (C) $\mathrm{Z}_{\mathrm{E}}$ as a function of water-column depth. Data are means \pm standard error (total $n=38$ ). Means with different letters are significantly different $(\mathrm{p} \leq 0.05)$.

resuspension and together explained ca. $70 \%$ of the total variability; $\mathrm{K}_{\mathrm{d}}$ coefficients, SPM and all phosphorus concentrations and $\mathrm{PON}$ and $\mathrm{N}-\mathrm{NO}_{3}$ concentrations explained ca. 47 and $22 \%$ of the variability within the first and second PC, respectively. Although mean SPM concentrations were similar between 


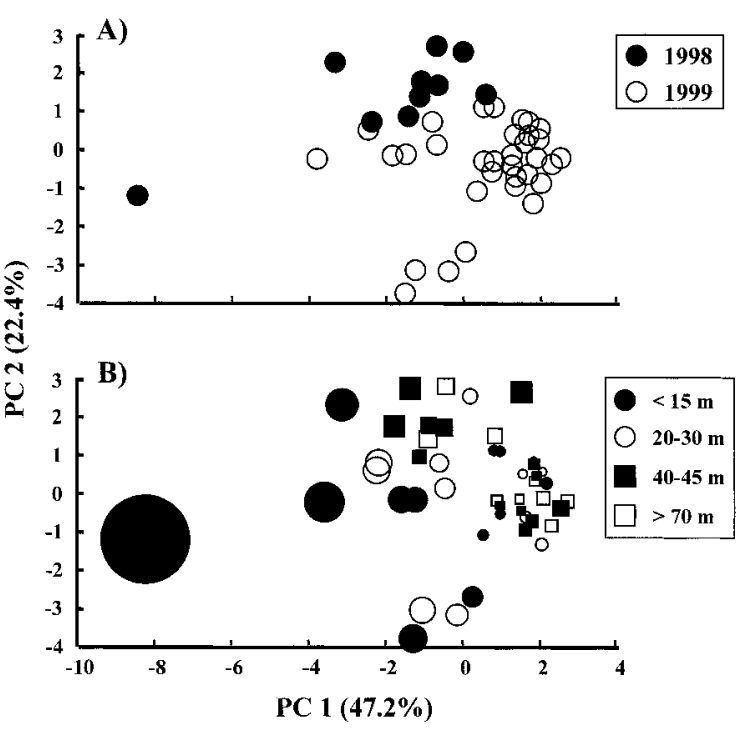

Figure 3. Two-dimensional principal components (PCs) ordination of sampling stations based on physical and chemical parameters. (A) Stations denoted as a function of sampling year (1998, $\mathrm{n}=10$; 1999, $\mathrm{n}=33$ ). (B) Total phosphorus concentrations superimposed (as symbols of differing sizes - the larger the symbol, the greater the relative value) on ordination to identify impact of resuspension as a function of water-column depth. Numbers in parentheses along axes represent percent of total variability explained by the corresponding PC (see Results).

years, TP, TDP, PP, SRP and $\mathrm{N}-\mathrm{NO}_{3}$ concentrations were greatest in 1998 (Table 1). TP, TDP, PP, and $\mathrm{NH}_{4}$ concentrations corresponded with SPM concentrations ( $\mathrm{p} \leq 0.0001, \mathrm{r}=0.92,0.56,0.83$, and 0.72 , respectively; $\mathrm{n}=48-53$ ) and similar to SPM concentrations, increased with increasing distance offshore (Figure 3B). SRP and PON concentrations were associated with SPM concentrations, but were highly variable $(\mathrm{p} \leq 0.01, \mathrm{r}=0.36 ; \mathrm{p} \leq 0.001, \mathrm{r}=0.50$, respectively). $\mathrm{N}^{-\mathrm{NO}_{3}}$ concentrations did not correspond with SPM concentrations $(\mathrm{p}>0.05)$.

Diatoms and/or cryptophytes dominated most phytoplankton assemblages (Table 2; see Millie et al., $2002 \mathrm{~b}$ for a detailed species listing). Numerous, small ( $<6 \mu \mathrm{m})$ phytoflagellates also were observed, particularly at nearshore stations in 1998. Total cell abundance and volume ( $\overline{\mathrm{x}} \pm$ S.E.) ranged from 648.1 \pm 138.5-1500.9 \pm 419.4 cells $\mathrm{ml}^{-1}$ and $186.1 \pm$ 33.3-227.5 $\pm 39.3 \mu \mathrm{m}^{3} \mu \mathrm{m}^{-1}$. Diatom abundance and volume ranged from 277.0 \pm 85.5-507.9 \pm 161.2 cells ml ${ }^{-1}$ and $50.9 \pm 19.9-164.5 \pm 32.3 \mu \mathrm{m}^{3}$ $\mu \mathrm{m}^{-1}$ across water-column depths $(<15,20-30,40-$ 45 , and $>70 \mathrm{~m}$ ). Total cell abundance was greater ( $\mathrm{p}$ $\leq 0.05)$ in 1998 than in $1999(979.2 \pm 163.8$ and
$588.5 \pm 73.7$ cells $\mathrm{ml}^{-1}$, respectively), but total volume was similar (ca. $205 \mu \mathrm{m}^{3} \mu \mathrm{m}^{-1}, \mathrm{p}>0.05$ ). Both total and diatom cell abundance and volume were similar between nearshore and offshore stations ( $\mathrm{p}>$ $0.05)$ within both the combined and annual data sets. Total cell volume and both diatom cell abundance and volume were not associated with SPM concentrations ( $\mathrm{p}>0.05)$. Total cell abundance corresponded with SPM concentrations $(\mathrm{r}=0.61, \mathrm{p} \leq 0.001, \mathrm{n}=30)$, due to the large number of small phytoflagellates exhibiting minimal biomass during 1998.

Rank similarity matrices for total phytoplankton abundance- and volume were comparable $(\rho=0.90$, $\mathrm{p} \leq 0.001$ ), resulting in a similar distribution of stations within respective ordinations. However, phytoplankton assemblages were dissimilar between 1998 and 1999 (Figure 4A) and, to some degree, among nearshore and offshore stations $(<15 \mathrm{~m}$ and 45/ $>70 \mathrm{~m}$ depth, respectively; Figure 4B). The annual dissimilarity resulted from greater biomass of the small centric diatoms, Cyclotella spp. and Cyclostephanos spp. and small phytoflagellates in 1998 and large, net diatoms in 1999 (Table 2). Interestingly, phytoplankton species composition, at a near-shore station (along the New Buffalo transect) profoundly impacted by sediment resuspension in 1999 was more similar to 1998 assemblages than to assemblages from all other 1999 stations (Figure 4B).

Diatoms displayed a spatial dissimilarity between nearshore and offshore stations (Figure 5A), reflecting distributions of resuspended sediment. Rank similarity matrices for diatom cell abundance and volume were comparable $(\rho=0.85, \mathrm{p} \leq 0.001)$, resulting in a similar distribution of stations between respective ordinations. To examine differences in diatom composition with respect to sediment resuspension, stations were classified as either low (L-, $<3$ $\mathrm{mg}^{-1}$ ) or high (HI-, $>3 \mathrm{mg} \mathrm{l}^{-1}$ ) SPM stations (Figure $5 \mathrm{~B}$ ). Greater biomass of small centric diatoms and various pinnate diatoms occurred at nearshore, HI-SPM stations whereas large, net taxa were more prominent at offshore, L-SPM stations (Table 3). Eleven diatoms, including the centrics (Cyclotella spp., C. ocellata Pantocsek, Cyclostephanos spp., Aulacoseira islandica (Müller) Simonsen, Aulacoseira italica (Ehrenberg) Simonsen) and the pennates ( $S$. filiformis Grunow, $F$. crotonensis Kitton, $F$. capucina Desmazieres, F. construens (Ehrenberg) Grunow, and Cocconeis pediculus Ehrenberg) comprised the species subset that 'best' approximated the ordination patterns derived using all diatoms (com- 
Table 1. Abiotic parameters for sampling stations along the Muskegon, St. Joseph, Cook, and Gary transects and representing both sediment-impacted and adjacent waters during 1998 ( $\mathrm{n}=10-21)$ and $1999(\mathrm{n}=32-34)$. Data are annual means + standard error. Minimum to maximum values are in parentheses. *, **, and *** indicates difference between means at $\mathrm{p} \leq 0.05,0.01$, and 0.001 respectively.

\begin{tabular}{lll}
\hline Parameter & 1998 & 1999 \\
\hline Suspended particulate matter $^{1}$ & $6.7 \pm 2.2(0.6-34.2)$ & $2.9 \pm 0.7(0.5-21.1)$ \\
Total dissolved phosphorus $^{2 * * *}$ & $2.5 \pm 0.2(1.4-4.4)$ & $1.2 \pm 0.1(0.7-2.1)$ \\
Particulate phosphorus $^{2 * * *}$ & $9.9 \pm 1.9(3.6-38.6)$ & $3.3 \pm 2.0(1.1-11.3)$ \\
Soluble reactive phosphorus $^{2 * * *}$ & $0.9 \pm 0.1(0.2-2.0)$ & $0.2 \pm 0.0(0.1-0.4)$ \\
Total phosphorus $^{2 *}$ & $12.4 \pm 3.1(5.6-46.1)$ & $6.0 \pm 0.5(3.0-15.9)$ \\
Nitrate-nitrogen $^{2 * *}$ & $265.0 \pm 24.8(125.0-566.7)$ & $368.1 \pm 20.4(266.0-763.0)$ \\
Ammonium $^{2}$ & $9.3 \pm 1.9(2.2-31.3)$ & $6.5 \pm 0.8(1.2-17.0)$ \\
Particulate organic nitrogen $^{1}$ & $0.03 \pm 0.01(0.01-0.12)$ & $0.03 \pm 0.00(0.02-0.06)$ \\
Particulate organic carbon $^{1}$ & $0.30 \pm 0.04(0.13-0.97)$ & $0.23 \pm 0.01(0.12-0.39)$ \\
Total silicate $^{1 *}$ & $1.4 \pm 0.1(1.3-2.1)$ & $1.6 \pm 0.0(1.4-1.9)$ \\
Particulate silicate $^{1}$ & $0.4 \pm 0.1(0.1-1.4)$ & $0.2 \pm 0.0(0.1-0.5)$ \\
Chloride $^{1}$ & $11.8 \pm 0.5(10.7-14.8)$ & $12.5 \pm 0.3(10.9-17.6)$ \\
\hline
\end{tabular}

${ }^{1} \mathrm{mg} \mathrm{L}^{-1} ;{ }^{2} \mu \mathrm{g} \mathrm{L}{ }^{-1}$

Table 2. Mean phytoplankton cell abundance (cells $\mathrm{ml}^{-1}$ ) and taxon contributions to total mean dissimilarity (=54.36) between 1998 and 1999 (refer to Figure 4). Taxa are ordered in decreasing contributions (as determined by Similarity Percentage Analysis, see Methods); only taxa contributing to the initial $75 \%$ of the total dissimilarity are listed.

\begin{tabular}{|c|c|c|c|c|c|}
\hline Taxon & 1998 & 1999 & $\begin{array}{l}\text { Dissimilarity, X } \\
\pm \text { S.D. }\end{array}$ & Contributing $\%$ & Cumulative $\%$ \\
\hline Cyclotella spp. & 296.6 & 63.1 & $8.0 \pm 1.8$ & 14.6 & 14.6 \\
\hline Phytoflagellates & 533.5 & 164.9 & $7.8 \pm 1.3$ & 14.4 & 29.0 \\
\hline Synedra filiformis Grunow & 11.1 & 120.0 & $5.7 \pm 1.7$ & 10.4 & 39.4 \\
\hline Rhodomonas minuta Skuja & 43.2 & 59.3 & $3.3 \pm 1.3$ & 6.0 & 45.4 \\
\hline Fragilaria crotonensis Kitton & 5.2 & 36.6 & $3.1 \pm 1.7$ & 5.7 & 51.1 \\
\hline Aulacoseira islandica (Müller) Simonsen & 10.5 & 28.8 & $2.0 \pm 1.4$ & 3.6 & 54.7 \\
\hline Aulacoseira italica (Ehrenberg) Simonsen & 23.6 & 23.4 & $1.9 \pm 1.4$ & 3.6 & 58.3 \\
\hline Cyclotella ocellata Pantocsek & 14.4 & 3.8 & $1.8 \pm 0.9$ & 3.2 & 61.5 \\
\hline Stephanodiscus medius Häkansson & 12.6 & 2.4 & $1.3 \pm 0.6$ & 2.4 & 63.9 \\
\hline Cyclostephanos spp. & 32.7 & 2.3 & $1.2 \pm 0.5$ & 2.3 & 66.1 \\
\hline Cyclotella kuetzingiana Thwaites & 0.0 & 18.8 & $1.2 \pm 0.4$ & 2.2 & 68.3 \\
\hline Synedra ulna var. chaseana Thomas & 0.2 & 4.4 & $1.1 \pm 1.0$ & 2.1 & 70.4 \\
\hline Aphanocapsa incerta (Lemmermann) Cronberg and Komárek & 26.9 & 0.0 & $1.1 \pm 0.3$ & 2.0 & 72.4 \\
\hline Nitzschia spp. & 0.3 & 7.1 & $1.1 \pm 0.7$ & 2.0 & 74.3 \\
\hline Asterionella formosa Hasall & 4.1 & 4.5 & $1.1 \pm 1.6$ & 1.9 & 76.2 \\
\hline
\end{tabular}

pare Figure 5C, Figure 5A) and validated results of the SIMPER analysis (Table 3). Sample groupings with similarity of $60 \%$ or greater, derived from hierarchical cluster analysis and superimposed on ordinations, verified the adequacy of the multivariate representations.

Integral production ranged from ca. 18-915 $\mathrm{mg} \mathrm{C}$ $\mathrm{m}^{-2}(\mathrm{n}=38$; Figure 6). Production values were positively associated $(r=0.62$ and $r=0.76 ; p \leq$ $0.0001)$ with values of $\bar{I}_{w c d}$ and $E_{Z}$, respectively (compare Figure 2C, Figure 6), but inversely associated $(\mathrm{r}=-0.70$ and $\mathrm{r}=-0.71 ; \mathrm{p} \leq 0.0001)$ with
SPM concentrations and $\mathrm{K}_{\mathrm{d}}$ coefficients, respectively. Depth-specific production, integral production normalized to mixing depth, was similar (ca. $4.6 \mathrm{mg} \mathrm{C}$ $\mathrm{m}^{-3}$ ) within water-column depths $<15$ and $>40$ $\mathrm{m}$, with the greatest values $\left(8.6 \mathrm{mg} \mathrm{C} \mathrm{m}^{-3}\right)$ occurring within a depth of 20-30 m. However, depth-specific production did not correspond $(\mathrm{p}>0.05)$ with either SPM concentrations or $\mathrm{K}_{\mathrm{d}}$ coefficients.

Values for $\mathrm{P}_{\max }^{\mathrm{B}}$ and $\alpha^{\mathrm{B}}$ ranged from 0.66-3.56 ( $\overline{\mathrm{x}}$ \pm S.E., $1.54 \pm 0.09) \mathrm{mg} \mathrm{C} \mathrm{mg} \mathrm{Chl}^{-1} \mathrm{hr}^{-1}$ and 2.80$12.47(5.13 \pm 0.26) \mathrm{mg} \mathrm{C} \mathrm{mg} \mathrm{Ch}^{-1} \mathrm{E} \mathrm{m}^{-2}$, respectively. $\mathrm{P}_{\max }^{\mathrm{B}}$ values were uniform throughout study 

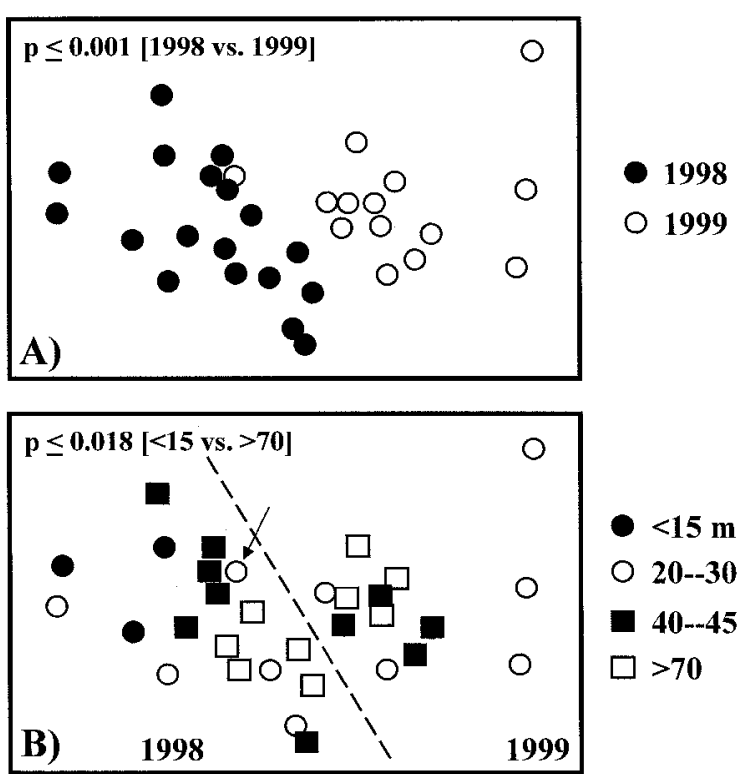

Figure 4. Multi-dimensional scaling ordinations of sampling stations based on Bray-Curtis similarities of phytoplankton. Cell abundance as a function of (A) sampling year (1998, $\mathrm{n}=18 ; 1999$, $\mathrm{n}=13)$ and (B) water-column depth $(<15 \mathrm{~m}, \mathrm{n}=3 ; 20-30 \mathrm{~m}, \mathrm{n}$ $=9 ; 40-45 \mathrm{~m}, \mathrm{n}=10 ;>70 \mathrm{~m}, \mathrm{n}=8)$, respectively. Statistical information derived from Analysis of Similarity (see Methods). Dashed line in panel B separates 1998 and 1999 stations (note: station point indicated by an arrow represents a 1999 sample). Stress $=0.12$.

years $(\mathrm{p}>0.05)$, but $\alpha^{\mathrm{B}}$ values were greater $(\mathrm{p} \leq$ 0.05) in 1998 than in 1999 and $2000(5.80 \pm 0.46$, $4.35 \pm 0.25$, and $4.8 \pm 0.36 \mathrm{mg} \mathrm{C} \mathrm{mg} \mathrm{Chl}^{-1} \mathrm{E} \mathrm{m}^{-2}$, respectively). Both $\mathrm{P}_{\max }^{\mathrm{B}}$ and $\alpha^{\mathrm{B}}$ values were greatest (2.29 $\pm 0.42 \mathrm{mg} \mathrm{C} \mathrm{mg} \mathrm{Chl}{ }^{-1} \mathrm{hr}^{-1}, \mathrm{p} \leq 0.05$ and $8.08 \pm 1.52 \mathrm{mg} \mathrm{C} \mathrm{mg} \mathrm{Chl}^{-1} \mathrm{E} \mathrm{m}^{-2}, \mathrm{p} \leq 0.001$, respectively) in water-column depths of $<15 \mathrm{~m}$. Although $\mathrm{P}_{\max }^{\mathrm{B}}$ and $\alpha^{\mathrm{B}}$ corresponded with both $\mathrm{K}_{\mathrm{d}}$ coefficients and SPM concentrations ( $\mathrm{p} \leq 0.001)$, relationships were rather variable $(\mathrm{r}=0.51-0.58)$ and appeared 'driven' by the relationship between photosynthetic parameters and a single, large SPM concentration in 1998 (Figure 7A, Figure 7B).

Values for $\mathrm{I}_{\mathrm{k}}$ ranged from $0.19-0.48 \mathrm{E} \mathrm{m}^{-2} \mathrm{hr}^{-1}$, with values uniform $(0.30 \pm 0.01 ; \mathrm{p}>0.05)$ across water-column depths and years. Comparisons of $\mathrm{I}_{\mathrm{k}}$ with $\overline{\mathrm{I}}_{\mathrm{wcd}}$ characterized light-limited or light-saturated conditions for photosynthesis. A three-day mean $\overline{\mathrm{I}}_{\mathrm{wcd}}$ (calculated using total irradiance for the day of the experiment and the preceding two days) 'averaged out' single-day variation and was consistent with respect to phytoplankton generation times (from Fahn- enstiel et al., 2000). Photosynthesis appeared both light-limited and light-saturated (indicated by ratios of $\mathrm{I}_{\mathrm{k}} \overline{\mathrm{I}}_{\mathrm{wcd}}^{-1}$ less than and greater than one, respectively; Figure 8A). Ratios of $\mathrm{I}_{\mathrm{k}} \overline{\mathrm{I}}_{\mathrm{wcd}}^{-1}$ were inversely dependent upon $\mathrm{EZ}_{\mathrm{d}} \mathrm{S}_{\mathrm{d}}^{-1}$ ratios $(\mathrm{r}=-70, \mathrm{p} \leq 0.0001, \mathrm{n}=$ 38). Those assemblages with lesser $E Z_{d} S_{d}^{-1}$ ratios exhibited $\mathrm{I}_{\mathrm{k}}$ values less than $\overline{\mathrm{I}}_{\mathrm{wcd}}$ values (the lower, right-hand section of Figure 8A), indicating light saturation. Except for one value (corresponding to an assemblage at an offshore station and having the lowest observed SPM concentration in 1998), these values corresponded with 1999 and 2000 assemblages. Conversely, assemblages with large $\mathrm{EZ}_{\mathrm{d}} \mathrm{S}_{\mathrm{d}}^{-1}$ ratios exhibited $\mathrm{I}_{\mathrm{k}}$ values greater than $\overline{\mathrm{I}}_{\mathrm{wcd}}$ values (the upper, left-hand section of Figure 8A), indicating light limitation. These values almost entirely corresponded with 1998 assemblages. The annual ratio of $\mathrm{I}_{\mathrm{k}} \overline{\mathrm{I}}_{\mathrm{wcd}}^{-1}$ was greatest in 1998 ( $\mathrm{p} \leq 0.001$, Figure 8B), whereas ratios for 1999 and 2000 approximated one, indicating the potential for both light-limitation and light-saturation within lake assemblages during this period.

Values of $\mu_{\mathrm{Chl}}$ ranged from $0.04-0.19 \mathrm{~d}^{-1}(\overline{\mathrm{x}} \pm$ S.E., $0.10 \pm 0.004, n=53)$. Values were greater $(p$ $\leq 0.001)$ at water-column depths of $20-30 \mathrm{~m}$ than at depths $>$ 40-45 $\mathrm{m}$ (Figure 9A), but were uniform among study years $(\mathrm{p}>0.05)$. Values of $\mu_{\mathrm{Chl}}$ corresponded with $\mathrm{K}_{\mathrm{d}}$ coefficients $(\mathrm{p} \leq 0.05)$, but the association was highly variable $(\mathrm{r}=0.30)$ and $\mu_{\mathrm{Chl}}$ did not correspond $(\mathrm{p}>0.05)$ with SPM concentrations. Although values of $\mu_{\max }$ were relatively similar $(0.10$ to $\left.0.13 \mathrm{~d}^{-1}\right)$ among study years, $\alpha_{\mu}$ values were variable $\left(0.03-0.08 \mathrm{E} \mathrm{m}^{-2}\right)$. This resulted in distinct $\mathrm{I}_{\mathrm{k}, \mu}$ values of 4.06, 1.87, and $1.26 \mathrm{E} \mathrm{m}^{-2} \mathrm{day}^{-1}$ in 1998, 1999, and 2000, respectively.

The relationship between values of light-saturated $\mu_{\mathrm{Chl}}$ and SPM concentrations was examined to assess the affects of resuspension-derived, nutrient stimulation on phytoplankton growth (independent of light limitation). Initially, assemblage growth rates were differentiated as either light-limited or light-saturated growth (based on annual $\mathrm{I}_{\mathrm{k}, \mu}$ values). Assemblages undergoing light-saturated growth comprised 33, 80, and $66 \%$ of all assemblages analyzed during 1998, 1999, and 2000, respectively. These assemblages then were classified into L- or HI-SPM station groups (as above). Although values of light-saturated $\mu_{\mathrm{Chl}}$ for Land HI-SPM groups were different ( $\mathrm{p} \leq 0.01$; Figure $9 \mathrm{~B}$ ), the disparity between means was 'driven' by the inclusion of an abnormally large value $\left(0.19 \mathrm{~d}^{-1}\right)$ 

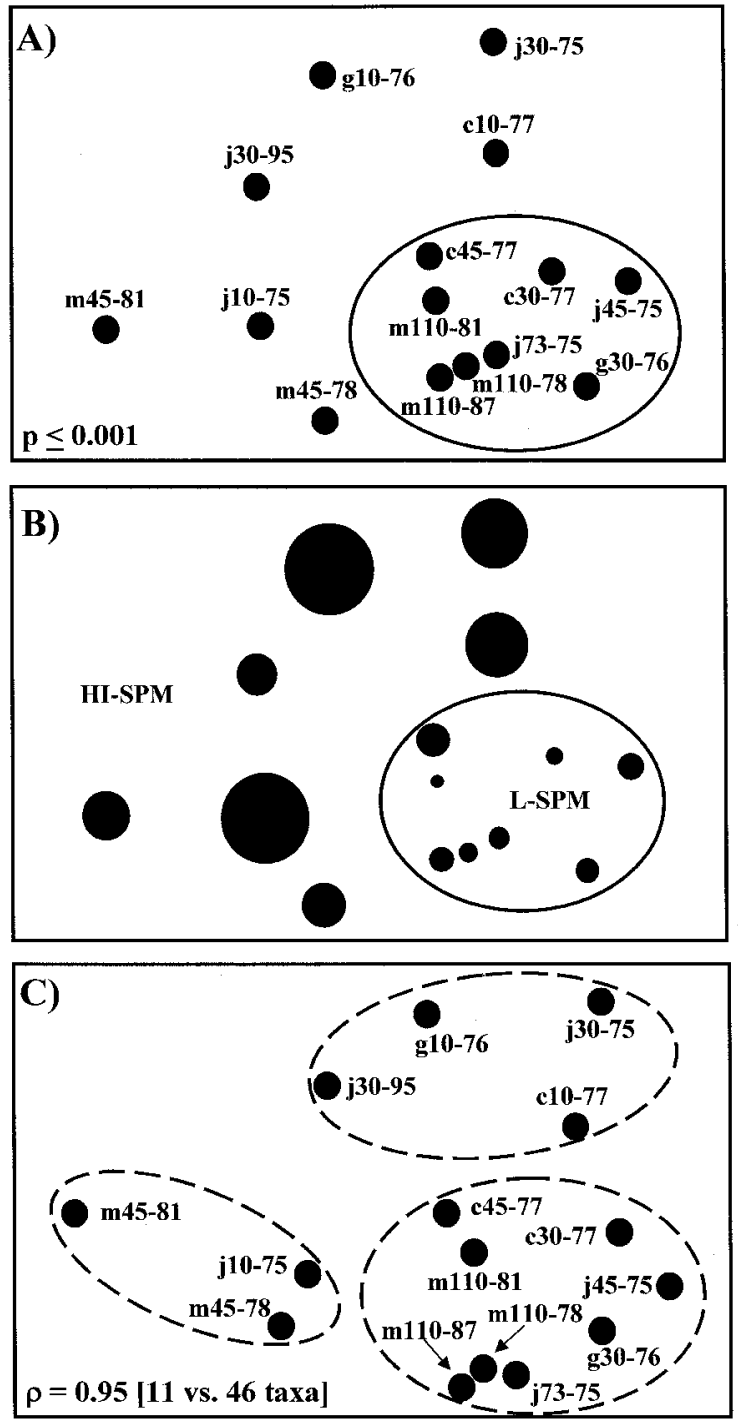

Figure 5. Multi-dimensional scaling ordinations of sampling stations based on Bray-Curtis similarities of 1998 diatom cell abundance. (A) Ordination using all (forty-six) diatoms. Labels designate sampling transect (C. Cook; G. Gary; J. St. Josesph; M. Muskegon), water-column depth (m) and day of year. Stress = 0.14. (B) Concentrations of suspended particulate matter (SPM) superimposed on ordination (the larger the symbol, the greater the relative value) to identify stations impacted by resuspension. Solid line differentiates groups designated as either low (L-, $<3 \mathrm{mg}$ $\mathrm{L}^{-1}$ ) or high (HI-, $\left.>3 \mathrm{mg} \mathrm{L}^{-1}\right)$ SPM impacted stations. Statistical information derived from Analysis of Similarity (see Methods). (C) Ordination using subset of eleven diatoms that best approximated the ordination using all taxa. The correlation coefficient indicates similarity between rank matrices for all diatoms and the diatom sub-set. Dashed lines enclose station groupings with compositional similarities of ca. $60 \%$ or greater, as derived from hierarchial cluster analysis. Stress $=0.11$. within the calculation of the mean rate for HI-SPM stations. When this rate was omitted, values of lightsaturated $\mu_{\mathrm{Chl}}$ for L- and HI-SPM stations were simi$\operatorname{lar}(\mathrm{p}>0.05)$.

\section{Discussion}

Within shallow marine and freshwater systems, infusion of meroplankton into the water column may alter phytoplankton biomass and/or composition (e.g., Lund 1954; Hartig 1987; Carrick et al. 1993, Schelske et al. 1995; Tester et al. 1995; Roy et al. 1996; Itakura et al. 1996; Imai and Itakura 1999). Resuspension events in Lake Michigan typically initiate in shallow, near-shore waters. Nalepa and Quigley (1987) reported that viable, benthic Chl a occurs within surficial sediments of near-shore Lake Michigan, with the greatest amounts (up to $212 \mu \mathrm{g} \mathrm{g}^{-1}$ sediment) observed during late spring. Millie et al. (2002a) identified this surfical sediment layer as a source of meroplanktonic diatoms and surmised that the lake's near-shore, water-column Chl $a$ concentrations (typically $1.8-4.75 \mu \mathrm{g} \mathrm{l}^{-1}$ ) could increase by as much as $1.5 \mu \mathrm{g} \mathrm{1}^{-1}$ during major, prolonged resuspension events.

Sediment resuspension impacted coastal phytoplankton assemblages in Lake Michigan. Phytoplankton cell abundance and volume were similar between near- and offshore waters and were not associated with water-column SPM concentrations. Rather, phytoplankton composition exhibited both an inter-annual variability and a spatial dissimilarity that mirrored sediment resuspension. During 1998 when almost all stations were impacted by resuspension, assemblages largely were comprised of small, centric diatoms and phytoflagellates. During 1999 when most stations were minimally impacted, assemblages largely were comprised of large, net and small centric diatoms, and to a lesser extent than 1998, phytoflagellates. Small, centric diatoms (Cyclostephanos spp. and Cyclotella spp.) exhibiting meroplanktonic life histories (after Beaver 1981) were predominant at sediment-impacted, nearshore stations. Kelly (2001) also noted that small centric diatoms comprised ca. 55\% of the water-column Chl $a$ concentrations within sediment-impacted waters whereas large, net centric diatoms accounted for less than 5\%. In contrast, large, net diatoms generally associated with optically-clear waters (e.g., A. islandica, A. italica, Synedra ulna (Nitzsch) Ehrenberg, F. crotonensis; 
Table 3. Mean diatom abundance (cells ml ${ }^{-1}$ ) and taxon contributions to total mean dissimilarity (= 50.4) between low (L-, $<3 \mathrm{mg} \mathrm{l}^{-1}$ ) or high (HI-, > $3 \mathrm{mg} \mathrm{l}^{-1}$ ) SPM impacted stations during 1998 (refer to Figure 5). Taxa are listed in decreasing contribution (as determined by Similarity Percentage Analysis, see Methods); only those taxa contributing the initial 75\% of the total dissimilarity are listed.

\begin{tabular}{|c|c|c|c|c|c|}
\hline Taxon & L-SPM & HI-SPM & $\begin{array}{l}\text { Dissimilarity, } \\
\bar{X} \pm \text { S.D. }\end{array}$ & $\begin{array}{l}\text { Contributing } \\
\%\end{array}$ & $\begin{array}{l}\text { Cumulative } \\
\%\end{array}$ \\
\hline Cyclotella spp. & 119.5 & 416.5 & $9.5 \pm 1.6$ & 18.8 & 18.8 \\
\hline Cyclostephanos spp. & 3.1 & 104.8 & $5.8 \pm 0.8$ & 11.4 & 30.2 \\
\hline Synedra filiformis Grunow & 11.9 & 9.6 & $3.5 \pm 1.4$ & 7.0 & 37.2 \\
\hline Aulacoseira italica (Ehrenberg) Simonsen & 29.2 & 18.8 & $3.3 \pm 1.3$ & 6.6 & 43.8 \\
\hline Cyclotella ocellata Pantocsek & 12.1 & 7.0 & $3.1 \pm 1.0$ & 6.2 & 50.0 \\
\hline Aulacoseira islandica (Müller) Simonsen & 10.9 & 5.5 & $2.7 \pm 1.4$ & 5.4 & 55.4 \\
\hline Fragilaria crotonensis Kitton & 8.4 & 1.9 & $2.6 \pm 1.0$ & 5.2 & 60.6 \\
\hline Fragilaria capucina Desmazieres & 0.2 & 12.2 & $2.5 \pm 0.8$ & 4.9 & 65.4 \\
\hline Cyclotella stelligera (Cleve and Grunow in Cleve) Van Heurck & 4.7 & 4.4 & $2.0 \pm 0.8$ & 3.9 & 69.3 \\
\hline Asterionella formosa Hasall & 1.4 & 6.1 & $1.9 \pm 1.5$ & 3.8 & 73.1 \\
\hline Meridion circulare Greville) Agardh & 0.0 & 7.9 & $1.9 \pm 0.6$ & 3.7 & 76.8 \\
\hline
\end{tabular}

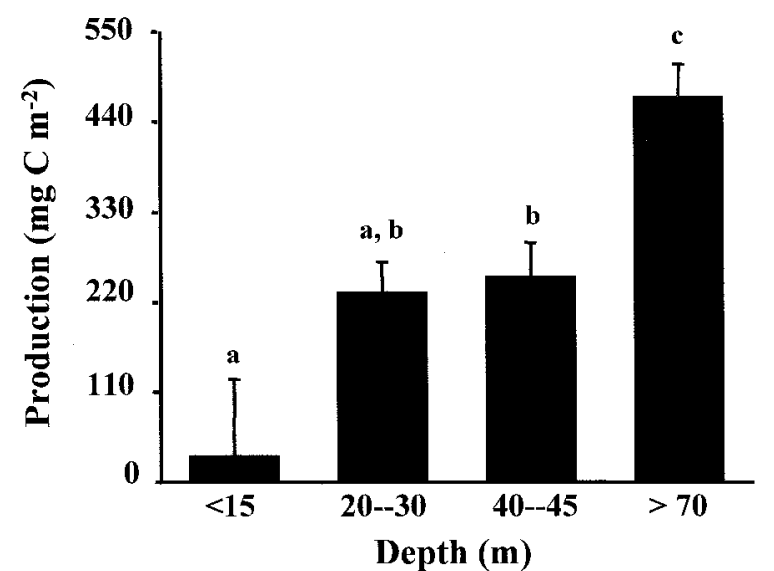

Figure 6. Integral production as a function of water-column depth. Data are means \pm standard error (total $n=37$ ). Means with different letters are significantly different $(\mathrm{p} \leq 0.05)$.

Scavia and Fahnenstiel, 1987) were predominant within assemblages having little or no association with resuspension. Although total Chl $a$ concentrations were not always uniform across near-shore/offshore gradients, Millie et al. (2002a) noted a lack of correspondence between both total and absolute diatom Chl $a$ concentrations and SPM concentrations.

Sediment resuspension altered the light and nutrient climate within nearshore waters of Lake Michigan. Although resuspension did not alter spectral light quality (see Bergman et al. 2003), increased attenuation corresponding to resuspended sediment did compress the photic zone into a small fraction of the water column. Ladewski and Stoermer (1973) attributed low transparencies within Lake Michigan near-shore waters to increased light extinction caused, in part, by
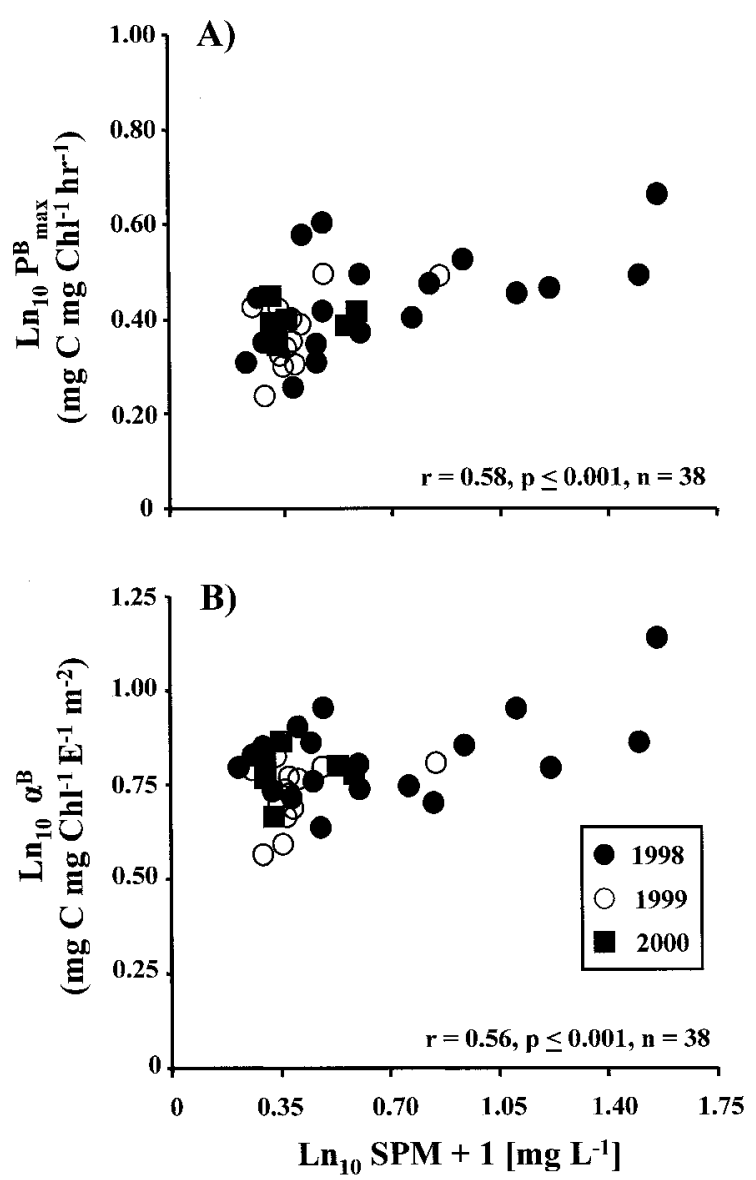

Figure 7. Relationships of (A) the maximum light-saturated photosynthetic rate $\left(\mathrm{P}_{\max }^{\mathrm{B}}\right)$ and $(\mathrm{B})$ photosynthetic efficiency $\left(\alpha^{\mathrm{B}}\right)$ with water-column concentrations of suspended particulate matter (SPM). Corresponding statistical information represents analyses performed on the entire data set. 

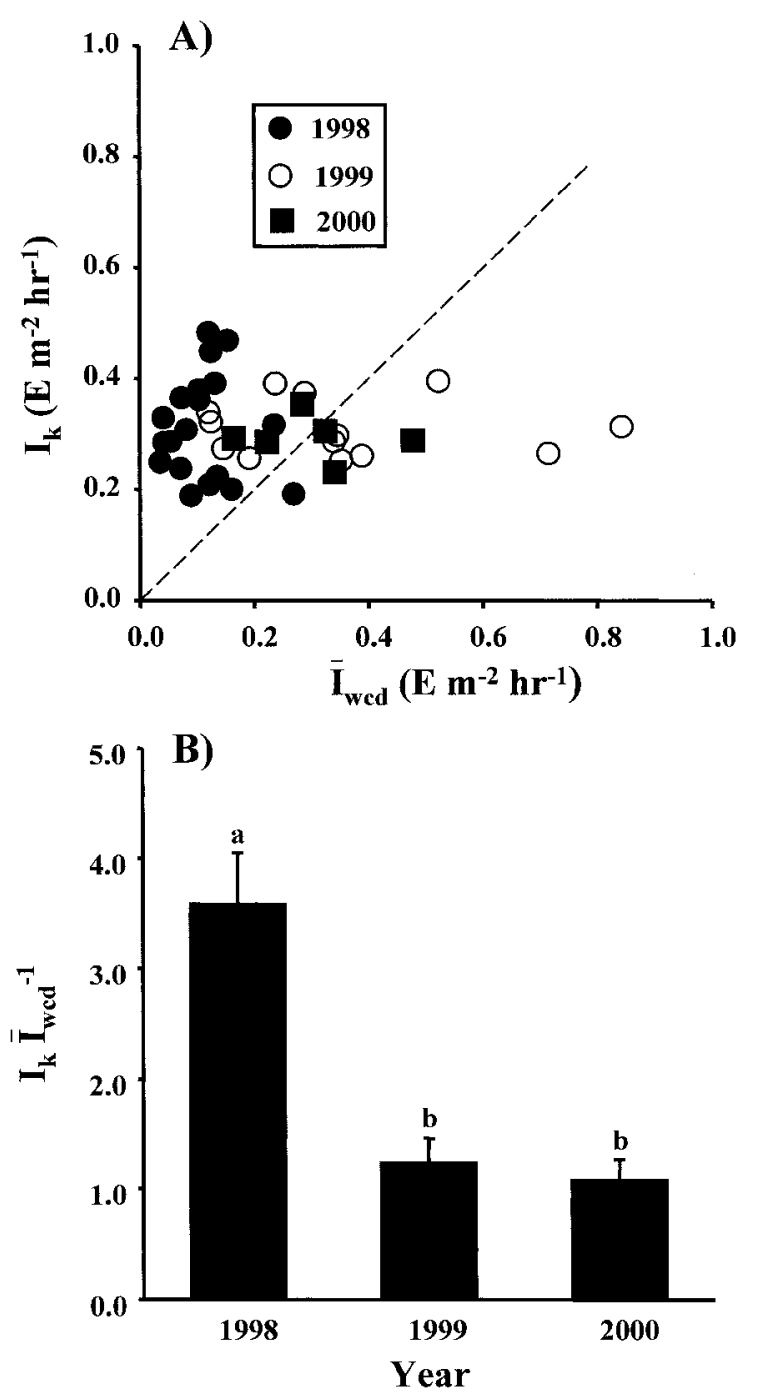

Figure 8. (A) Relationship of the photosynthetic saturation irradiance $\left(\mathrm{I}_{\mathrm{k}}\right)$ with a three-day mean irradiance within the mixed layer ( $\overline{\mathrm{I}}_{\mathrm{wcd}}$; see Methods). The dashed line represents a 1:1 relationship. (B) Annual ratios of $\mathrm{I}_{\mathrm{k}} \overline{\mathrm{I}}_{\mathrm{wcd}}^{-1}$. Data are means \pm standard error (total $\mathrm{n}=38$ ). Means with different letters are significantly different $(\mathrm{p} \leq 0.05)$.

the occurrence of 'milky-colored' water (similar to the color of waters within locales undergoing intense sediment resuspension in this study). Moreover, sediment resuspension corresponded with increased nutrient concentrations, particularly diverse forms of phosphorus, within impacted waters (also see Cotner et al. 2000). Phosphorus is the nutrient considered most limiting for both phytoplankton photosynthesis and growth throughout all the Great Lakes (Schelske et. al. 1974, 1986; Fahnenstiel et al. 1998).
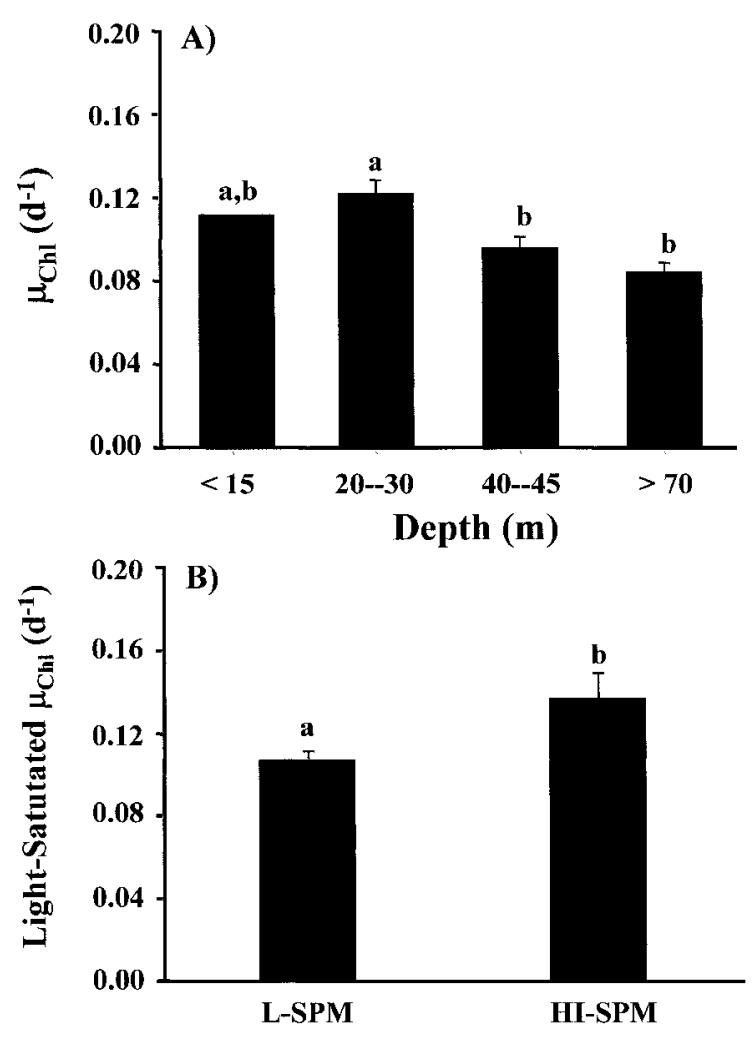

Figure 9. (A) Chlorophyll-specific growth rates $\left(\mu_{\mathrm{Chl}}\right)$ as a function of water-column depth. Data are means \pm standard error (total $\mathrm{n}=54$ ). (B) Light-saturated growth rates as a function of low $\left(\mathrm{L}-,<3 \mathrm{mg} \mathrm{L}^{-1} ; \mathrm{n}=32\right)$ or high (HI-, $\left.>3 \mathrm{mg} \mathrm{L}^{-1} ; \mathrm{n}=6\right) \mathrm{SPM}$ impacted stations. Data are means \pm standard error. Means with different letters are significantly different $(\mathrm{p} \leq 0.05)$.

Sediment resuspension appeared to impact phytoplankton photosynthesis. Integral production, estimated by the GLPM, increased with increased watercolumn depth, reflecting the enlarged euphotic zone within optically-clear, offshore waters. Because Chl $a$ is uniform throughout the lake's water column during this period (Millie et al. 2002a) and the GLPM is highly sensitive to variability in light attenuation and phytoplankton biomass (but less so to alterations in photosynthetic parameters; Lang and Fahnenstiel 1996), nearshore resuspension appeared to reduce production. Both $\mathrm{P}_{\max }^{\mathrm{B}}$ and $\alpha^{\mathrm{B}}$ corresponded with resuspension, potentially reflecting altered light harvesting and utilization and/or nutrient stimulation within impacted assemblages. However, the values most influencing these associations corresponded to an assemblage from the 10-m isobath along the Gary transect in March, 1998. This station was situated immediately offshore $(0.5 \mathrm{~km})$ and with the most nearshore station (10-m depth) along the St. Joseph 
transect during this same period, had the greatest observed sediment resuspension (ca. $35 \mathrm{mg} \mathrm{l}^{-1}$ ).

Because measurements of both $\mathrm{P}_{\max }^{\mathrm{B}}$ and $\alpha^{\mathrm{B}}$ are dependent, in part, upon phytoplankton structure and composition (Dunstan 1973; Harris 1973), any apparent differences in photosynthetic parameters between SPM- and non-impacted assemblages likely reflected species (and corresponding physiological) dissimilarities. Photosynthetic pigments are more efficient if they are packaged in small cells than in large ones; the specific absorption coefficient at the red $\mathrm{Chl}$ maximum is ca. $6 \mathrm{x}$-greater for $1-\mu \mathrm{m}$ diameter cells than for 100- $\mu \mathrm{m}$ diameter cells (Fogg 1991). In diatoms, the optical absorption cross section decreases with increasing cell size, thereby confirming a competitive advantage to small cells under nutrient-sufficient and both light-saturating and light-limited conditions (Geider et al. 1986). Kelly (2001) observed that biomass-specific light absorption for $C y$ clotella spp. and Cyclostephanos spp. was substantially greater than that for Aulacoseira spp. within sediment-impacted waters whereas absorption was comparable among species within optically-clear waters. Furthermore, all measures for phosphorus deficiency (including alkaline phosphatase activity, phosphorus-33 turnover, presence of poly-phosphate bodies) indicated no significant limitation within the lake's phytoplankton prior to and during resuspension events (G. Fahnenstiel, unpubl.).

Photosynthesis in the lake's assemblages appeared light-limited (or nearly so) and although sediment resuspension was variable, maximum rates were relatively similar among years. Phytoplankton undergoing rapid vertical mixing (such as that within an isothermal water column) are subject to continuously varying amounts of irradiance and may exist the majority of time within the aphotic zone (Fogg 1991; Fahnenstiel et al. 2000). Kelly (2001) concluded that rates of water-column mixing within coastal Lake Michigan likely are greater than rates of cellular acclimation and cells would photoacclimate to the average light level within the mixed layer. However, the passage of cells from optimal to sub-optimal irradiance conditions column likely occurs over intensely repetitive, short-time intervals. Consequently, the photosynthesis a cell undertakes within sediment-impacted coastal waters does not simply correspond to the average irradiance to which it has been exposed (Fogg 1991), but also the total amount.

The (light-saturated) growth rates corresponding with sediment-impacted assemblages indicated an apparent stimulation of phytoplankton growth, potentially due to the infusion of biologically-important nutrients with resuspension. However, increased growth rates also may reflect, in part, the infusion of transient phytoplankton and nutrient inputs within tributary inflows (e.g., Schelske et al. 1984; Klarer and Millie 1989; Klarer and Millie 1994, Biddanda and Cotner 2002). Although the mean light-saturated growth rate for assemblages at HI-SPM stations was slightly (albeit significantly) greater than that at L-SPM stations, the rate most influencing this difference corresponded to an assemblage from the 30-m isobath along the Saint Joseph transect in April, 1999. This station lies immediately offshore of the confluence of the Saint Joseph River and the lake. Previously, Millie et al. (2002a) reported a sizeable introduction of riverine $\mathrm{Chl} a$ to nearshore assemblages along this transect during this same time. Chang and Rossman (1988) and Biddanda and Cotner (2002) also noted that the St. Joseph River is a major point source of nutrients and dissolved organic carbon into the lake. Increased resuspension from nearshore turbulence by pronounced riverine inflows also may have added meroplanktonic/benthic taxa to this 'mixed' coastal assemblage of lake and riverine taxa. Nevertheless, growth rates for (both light-limited and light-saturated) coastal assemblages were quite low $\left(0 \pm\right.$ S.E., $\left.0.10 \pm 0.004 \mathrm{~d}^{-1}\right)$ throughout the study and it would be difficult to accredit an apparent (slight) increase to a single factor.

Overall, sediment resuspension appears to have little, if any long-term impact on the structure and function of the lake's phytoplankton. In marine and freshwater systems, resuspension of meroplankton may act as a 'seeding' mechanism for planktonic assemblages; under optimal environmental conditions, resuspended cells/cysts may undergo selective growth, 'out-compete' other phytoplankton, and potentiate blooms (e.g., Smetacek 1985; Imai et al. 1996; Imai and Itakura 1999). Within Lake Michigan, resuspension events typically coincide with the initiation of the spring phytoplankton bloom (see Brooks and Torke 1977; Fahnenstiel and Scavia 1987b; Scavia and Fahnenstiel 1987; Gardner et al. 1990; Fitzgerald and Gardner 1993) and many of the diatoms typically comprising the bloom have been observed as meroplankton within other systems (SickoGoad et al. 1986; Sicko-Goad et al. 1989). Eadie et al. (1984) hypothesized that the nutrients required for the spring bloom may originate internally from the lake's sediments (also see Conley et al. 1988). Mor- 
timer (1988) suggested that resuspension, in conjunction with cross-shelf transport of resuspended taxa and/or nutrients, might provide for development of the spring bloom within nutrient-rich, near-shore waters prior to its propagation offshore. Such an internal 'flux' would be thought to play an important biogeochemical role in delineating both the biomass potential and duration of the spring bloom (see Scavia and Fahnenstiel 1987; Eadie et al. 2002) and dramatically alter system-level production and trophic state. However, the diatoms (e.g., A. islandica, A. italica) associated with offshore, optically-clear waters and typically dominate the spring bloom were distinct from those associated with sediment resuspension.

Sediment resuspension increased the potential for light limitation within impacted assemblages, while reducing the potential for nutrient-light interactions (after Fahnenstiel et al. 1984; Fahnenstiel et al. 2000). In phytoplankton, the uptake and utilization of nutrients link photosynthesis to cell growth (Cullen 2002). However, light and nutrient availability often are near the threshold levels for limitation during the spring isothermal period and even in the absence of such limitation, photosynthesis and growth only can maximize up to the cellular capacity for any given species and temperature (Fahnenstiel et al. 1989; Fahnenstiel et al. 2000). Although photosynthetic efficiency/ capacity and cell growth rates appeared to correspond with resuspension (potentially reflecting enhanced physiological rate processes within sediment-impacted assemblages), these measurements represented 'bulk' community assessments. Phytoplankton response to synoptic-scale environmental alteration or disturbance (such as episodic resuspension) typically occurs at the level of discrete organisms and individual species often exhibit metabolic rates distinct from the mean assemblage rate (e.g., Fahnenstiel et al. 1995b). Consequently, understanding the mechanisms that regulate phytoplankton physiological rate processes within dynamic coastal waters depends upon discerning resource utilization on a species-specific level; phytoplankton assemblages simply cannot be treated collectively as 'little bags of Chl' (Cullen 2002).

Undoubtedly, multiple factors interact to influence phytoplankton assemblages within coastal waters. Although the findings presented here may not be characteristic of all systems, Lake Michigan is large enough to be representative of marine ecosystems and the annual recurrence of sediment resuspension within the lake's 'closed' southern basin provided a magnified, yet repeatable examination of physical forcing upon coastal phytoplankton. Resuspension events altered the nutrient and light climate, phytoplankton composition, and potentially, the outcome of resource-based competition within the near-shore water column. However, it cannot be discounted that water temperatures (ca. $1-4{ }^{\circ} \mathrm{C}$ ) during the spring isothermal period are considered sub-optimal for physiological rate processes (Stoermer and Ladewski 1976; c.f. Makarewicz et al. 1979; Barbiero et al. 2000). Under such variable environmental conditions, only those taxa exhibiting the greatest physiological plasticity to biogeochemical and/or temperature influences would be conveyed a competitive advantage. Consequently, despite any holistic nutrient stimulation and/or infusion of low-light adapted meroplankton from the sediments during resuspension, the low water temperatures likely would constrain phytoplankton metabolic processes related to maximum growth and/or photoacclimation (Epply 1972; Fahnenstiel et al. 2000; Kelly 2001). Only if prolonged until warmer temperatures during the onset of thermal stratification, would sediment resuspension (and any corresponding competitive advantages of associated meroplankton) be anticipated to alter the development of the spring phytoplankton bloom in Lake Michigan.

\section{Conclusions}

1. Sediment resuspension was an annually-recurrent, yet spatially episodic coastal feature in southern Lake Michigan during the spring isothermal periods from 1998 to 2000. Resuspension events impacted the particle density, light field, and nutrient climate of the nearshore water-column. Increased light attenuation by resuspended particulate matter compressed the euphotic zone into a smaller fraction of the water column. Resuspension also increased concentrations of biologically-important nutrients, including diverse forms of phosphorus, within impacted waters.

2. Phytoplankton cell volume and diatom cell abundance and volume exhibited uniform distributions across near-shore/offshore gradients and were not associated with sediment resuspension. However, a distinct association between phytoplankton composition and sediment resuspension indicated that resuspension events provided a significant 'pulse' of benthic taxa into the water column. Small centric 
diatoms exhibiting meroplanktonic life histories and large, pennate diatoms considered benthic in origin were abundant within near-shore, sedimentimpacted waters whereas taxa typically associated with optically-clear, offshore waters were not.

3. Integral production was not associated with resuspended particulate matter and was greatest offshore, undoubtedly due to the enlarged, euphotic zone within optically-clear waters. Although the photosynthetic capacity/efficiency of assemblages appeared greatest at sites undergoing substantial resuspension, the potential for both light-limitation and light-saturation of photosynthesis during the spring isothermal period existed. During 1998, when the extent and intensity of sediment resuspension was greatest, photosynthesis was almost entirely light-limited. During 1999 and 2000, photosynthesis appeared both light-limited and light saturated.

4. Chlorophyll-specific growth rates were consistently low throughout the study. Light-saturated growth rates of phytoplankton appeared to correspond with light attenuation within the water column, potentially indicating a stimulation of growth by infusion of biologically-important nutrients associated with benthic-derived sediments. However, the extremely low water temperature throughout the spring isothermal period is considered sub-optimal for metabolic rate processes of phytoplankton and most likely, constrained the potential for maximum growth.

5. Episodic sediment resuspension does not appear to have a long-term impact upon the lake's phytoplankton. The lack of association between phytoplankton typically comprising the basin-wide spring bloom and sediment resuspension signified little, if any correspondence between resuspension and the development of the spring phytoplankton maximum. Most likely, any apparent differences of metabolic rate processes between sediment- and non-impacted assemblages reflected short-term compositional (and corresponding physiological) variations due to infusion of meroplankton and/or tributary-derived phytoplankton rather than community-level alterations to physical/chemical forcing.

\section{Acknowledgements}

This work is a portion of the research program, Episodic Events - Great Lakes Experiment (EEGLE): "The Impact of Episodic Events on the NearshoreOffshore Transport and Transformation of Biogeochemically Important Materials in the Great Lakes", funded by the National Oceanic and Atmospheric Administration, Coastal Ocean Program and the National Science Foundation, Coastal Ocean Processes. We thank the crew of the $R V$ Laurentian for their professional assistance and Larry Boihem, Augie Kotlewski, and Richard Stone for assisting in preparation, sampling, and sample analyses. Satellite imagery was provided by the National Oceanic and Atmospheric Administration, Great Lakes Coast Watch Program. Reference to proprietary names are necessary to report factually on available data; however, the Florida Institute of Oceanography, the National Oceanic and Atmospheric Administration, the Pennsylvania State University, the University of Michigan, and the University of Southern Mississippi neither guarantee nor warrant the standard of a product and imply no approval of a product to the exclusion of others that may be suitable.

\section{References}

Barbiero R.P., Carrick H.J., Volerman J.B., and Tuchman M.L. 2000. Factors affecting temporal and spatial distribution of diatoms in Lake Michigan. Verh. Internat. Verein. Limnol. 27: 1788-1794.

Beaver J. 1981. Apparent ecological characteristics of some common freshwater diatoms. Ontario Ministry of the Environment (517 pp.). Don Mills, Ontario, Canada.

Bergman T., Fahnenstiel G.L., Lohrenz S.E., Millie D.F. and Schofield O.M.E. 2002-in press. The impacts of a recurrent resuspension event and variable phytoplankton community composition on remote sensing reflectance. J. Geophys. Res.

Biddanda B.A. and Cotner J.B. 2002. Love handles in aquatic ecosystems: the role of dissolved organic carbon drawdown, resuspended sediments, and terrigenous inputs in the carbon balance of Lake Michigan. Ecosystems 5: 431-445.

Brooks A.S. and Eddington D.N. 1994. Biogeochemical control of phosphorus cycling and primary production in Lake Michigan. Limnol. Oceanogr. 39: 961-967.

Brooks A.S. and Torke B.G. 1977. Vertical and seasonal distribution of Chl a in Lake Michigan. J. Fish. Res. Board Can. 34: 2280-2287.

Carrick H.J., Aldridge F.J. and Schelske C.L. 1993. Wind influences phytoplankton biomass and composition in a shallow, productive lake. Limnol. Oceanogr. 38: 1179-1192. 
Chang W.Y.B. and Rossmann R. 1988. Changes in the abundance of blue-green algae related to nutrient loadings in the nearshore of Lake Michigan. Hydrobiologia 157: 271-278.

Clarke K.R. and Warwick R.M. 2001. Change in marine communities: an approach to statistical analyses and interpretation, 2nd ed. Primer-E, Plymouth, UK.

Clarke K.R. and Gorley R.N. 2001. PRIMER v5: User Manual/Tutorial. Primer-E, Plymouth, UK.

Claustre H., Kerherv P., Marty J.C., Prieur L., Videau C. and Hecq J.-H. 1994. Phytoplankton dynamics associated with a geostrophic front: ecological and biogeochemical implications. J. Mar. Res. 52: 711-742.

Cloern J.E. 1987. Turbidity as a control on phytoplankton biomass and productivity in estuaries. Cont. Shelf. Res. 7: 1367-1381.

Conley D.J., Quigley M.A. and Schelske C.L. 1988. Silica and phosphorus flux from sediments: importance of internal recycling in Lake Michigan. Can. J. Fish. Aquat. Sci. 45: 1030-1035.

Cotner J.B., Johengen T.H. and Biddanda B. 2000. Intense winter heterotrophic production stimulated by benthic resuspension. Limnol Oceanogr 45: 1672-1676.

Cullen J.J. 2002. Phytoplankton productivity. J. Phycol. 38: 12731275.

Davis C.O. and Simmons M.S. 1979. Water Chemistry and Phytoplankton Field and Laboratory Procedures, Great Lakes Research Division Special Report No. 70. University of Michigan, Ann Arbor, Michigan, USA.

Demers S., Therriault J.-C., Bourget E. and Desilets H. 1989. Small-scale gradients of phytoplankton productivity in the littoral fringe. Mar. Biol. 100: 393-399.

Dunstan W.M. 1973. A comparison of the photosynthesis-light intensity relationship in phylogenetically-different microalgae. J. Exp. Mar. Biol. Ecol. 13: 181-187.

Eadie B.J., Chambers R.L., Gardner W.S. and Bell G.L. 1984. Sediment trap studies in Lake Michigan: resuspension and chemical fluxes in the southern basin. J. Great Lakes Res. 10: 307-321.

Eadie B.J., Schwab D.J., Johengen T.H., Lavrentyev P.J., Miller G.S., Holland R.E., Leshkevich G.A., Lansing M.B., Morehead N.R., Robbins J.A., Hawley N., Edgington D.N. and Van Hoof P.L. 2002. Particle transport, nutrient cycling, and algal community structure associated with a major winter-spring sediment resuspension event in southern Lake Michigan. J. Great Lakes Res. 28: 324-337.

Eadie B., Schwab D., Assel R., Hawley N., Lansing B., Miller R., Morehead N. and Robbins J. 1996. Development of recurrent coastal plume in Lake Michigan observed for the first time. EOS Trans Am. Geophys. Union 77: 337-338.

Epply R.W. 1972. Temperature and phytoplankton growth in the sea. Fish. Bull. S. 70: 1063-1085.

Fahnenstiel G.L. and Scavia D. 1987a. Dynamics of Lake Michigan phytoplankton: primary production and growth. Can. J. Fish. Aquat. Sci. 44: 499-508.

Fahnenstiel G.L. and Scavia D. 1987b. Dynamics of Lake Michigan phytoplankton: recent changes in surface and deep communities. Can. J. Fish. Aquat. Sci. 44: 509-514.

Fahnenstiel G.L., Scavia D. and Schelske C.L. 1984. Nutrient-light interactions in the Lake Michigan subsurface Chl layer. Verh. Internat. Verein. Limnol. 22: 440-444.

Fahnenstiel G.L., Chandler J.F., Carrick H.J. and Scavia D. 1989. Photosynthetic characteristics of phytoplankton communities in
Lakes Huron and Michigan: P-I parameters and end-products. J. Great Lakes Res. 15: 394-407.

Fahnenstiel G.L. Krause A.E., McCormick M.J., Carrick H.J. and Schelske C.L. 1998. The structure of the planktonic food-web in the St. Lawrence Great Lakes. J. Great Lakes Res. 24: 531- 544.

Fahnenstiel G.L., McCormick M.J., Lang G.A., Redalge D.G., Lohrenz S.E., Markowitz M., Wagoner B. and Carrick H.J. 1995b. Taxon-specific growth and loss rates for dominant phytoplankton populations from the northern Gulf of Mexico. Mar. Ecol. Prog. Ser. 117: 229-239.

Fahnenstiel G.L., Stone R.A., McCormick M.J., Schelske C.L. and Lohrenz S.E. 2000. Spring isothermal mixing in the Great Lakes: evidence of nutrient limitation and nutrient-light interactions in a suboptimal light environment. Can. J. Fish. Aquat. Sci. 57: 1901-1910.

Fahnenstiel G.L., Beckmann C., Lohrenz S.E., Millie D.F., Schofield O.M.E. and McCormick M.J.M. 2002. Standard Niskin and Van Dorn bottles inhibit phytoplankton photosynthesis in Lake Michigan. Verh. Internat. Verein. Limnol. 28: 376380.

Fahnenstiel G.L., Bridgeman T.B., Lang G.A., McCormick M.J. and Nalepa T.F. 1995a. Phytoplankton productivity in Saginaw Bay, Lake Huron: effects of zebra mussels (Dreissena polymorpha) colonization. J. Great Lakes Res. 21: 465-475.

Fitzgerald S.A. and Gardner W.S. 1993. An algal carbon budget for pelagic/benthic coupling. Limnol. Oceanogr. 38: 547-560.

Fogg G.E. 1991. The phytoplanktonic ways of life. New Phytol. 118: 191-232.

Gardner W.S., Quigley M.A., Fahnenstiel G.L., Scavia D. and Frez W.A. 1990. Pontoporeia hoyi - a direct trophic link between spring diatoms and fish in Lake Michigan. In: Tilzer M.M. and Serruya C. (eds), Large Lakes Ecological Structure and Function. Springer-Verlag, New York, New York, USA, pp. 632-644.

Geider R.J., Platt T. and Raven J.A. 1986. Size dependence of growth and photosynthesis in diatoms: a synthesis. Mar. Ecol. Prog. Ser. 30: 93-104.

Harris G.P. 1973. Diel and annual cycles of net plankton photosynthesis in Lake Ontario. J. Fish. Res. Board Can. 30: 1179-1187.

Hartig J.H. 1987. Factors contributing to the development of Fragilaria crotonensis Kitton pulses in Pigeon Bay waters of western Lake Erie. J. Great Lakes Res. 13: 65-77.

Imai I., Itakura S., Yamaguchi M. and Honjo T. 1996. Selective germination of Heterosigma akashiwo (Raphidophyceae) cysts in bottom sediments under low light conditions: a possible mechanism of red tide initiation. In: Yasumoto T., Oshima Y. and Fukuyo Y. (eds), Harmful and Toxic Algal Blooms Intergovern Oceanogr. Comm UNESCO, Paris, France, pp. 197-200.

Imai I. and Itakura S. 1999. Importance of cysts in the population dynamics of the red tide flagellate Heterosigma akashiwo. Mar. Biol. 133: 755-762.

Itakura S., Nagasaki K., Yamaguchi M. and Imai I. 1996. Species succession between Skeletonema costatum and Heterosigma akashiwo in Hiroshima Bay, Japan, with special reference to the resting stage cells in the bottom sediments. In: Yasumoto T., Oshima Y. and Fukuyo Y. (eds), Harmful and Toxic Algal Blooms, pp. 373-376. Intergovern Oceanogr. Comm. UNESCO, Paris, France.

Kelly K.A. 2001. The effects of a recurrent coastal plume on the absorption characteristics of phytoplankton species in Lake Michigan. M. Sci. Thesis, The University of Southern Mississippi, Hattiesburg, USA. 
Klarer D.M. and Millie D.F. 1989. Amelioration of storm-water quality by a freshwater estuary. Arch für Hydrobiol 116: 375389.

Klarer D.M. and Millie D.F. 1994. Regulation of phytoplankton dynamics in a Laurentian Great lakes estuary. Hydrobiologia 286: $97-108$

Ladewski T.B. and Stoermer E.F. 1973. Water transparency in southern Lake Michigan in 1971 and 1972. In Proc 16th Conf. Great Lakes Res., pp. 791-807. Internat. Assoc. Great Lakes Res.

Lang G.A. and Fahnenstiel G.L. 1996. Great Lakes primary production model - methodology and use, Technical Memorandum ERL GLERL-90. NOAA, US Dept. Comm., Ann Arbor, Michigan, USA.

Lohrenz S.E., Wiesenburg D.A., De Palma I.P., Johnson K.S. and Gustafson D.E. 1988. Interrelationships among primary production, Chl, and environmental conditions in frontal regions of the western Mediterranean Sea. Deep-Sea Res. 35: 793 - 810

Lund J.W.G. 1954. The seasonal cycle of the plankton diatom, Melosira italica (Her.) subsp. subarctica O. Mull. J. Ecol. 42: 151-179.

Makarewicz J.C., Baybutt R.I. and Damann K. 1979. Changes in the apparent temperature optima of the plankton of Lake Michigan at Chicago, Illinois. J. Fish. Res. Board Can. 36: 1169-1173.

Menzel D.W. and Corwin N. 1965. The measurement of total phosphorus liberated in seawater based on the liberation of organically bound fractions by persulfate oxidation. Limnol. Oceanogr. 10: 280-281.

Millie D.F., Fahnenstiel G.L., Carrick H.J., Lohrenz S.E. and Schofield O.M.E. 2002a. Phytoplankton pigments in coastal Lake Michigan: distributions during the spring isothermal period and relation with episodic sediment resuspension. J. Phycol. 38: 639-648.

Millie D.F., Fahnenstiel G.L., Carrick H.J., Lohrenz S.E. and Schofield O.M.E. 2002b. Spatial variation in Lake Michigan phytoplankton composition during sediment resuspension events. Verh. Internat. Verein. Limnol. 28: 1216-1220.

Mortimer C.H. 1988. Discoveries and testable hypotheses arising from the Coastal Zone Color Scanner imagery of southern Lake Michigan. Limnol. Oceanogr. 33: 203-226.

O’Donohue M.J. and Dennison W.C. 1997. Phytoplankton productivity response to nutrient concentration, light availability and temperature along an Australian estuarine gradient. Estuaries 20: 521-33.

Roy S., Chanut J.-P., Gosselin M. and Sime-Ngando T. 1996. Characterization of phytoplankton communities in the lower St. Lawrence Estuary using HPLC-detected pigments and cell microscopy. Mar. Ecol. Prog. Ser. 142: 55-73.

Scavia D. and Fahnenstiel G.L. 1987. Dynamics of Lake Michigan phytoplankton: mechanisms controlling epilimnetic communities. J. Great Lakes Res. 13: 103-120.
Schelske C.L., Feldt L.E., Simmnos M.S. and Stoermer E.F. 1974. Storm induced relationships among chemical conditions and phytoplankton in Saginaw Bay and western Lake Huron. In: Proc 17th Conf. Great Lakes Res. pp. 78-91. Internat. Assoc. Great Lakes Res.

Schelske C.L., Stoermer E.F., Fahnenstiel G.L. and Haibach M 1986. Phosphorus enrichment, silica utilization, and biogeochemical silica depletion in the Great Lakes. Can. J. Fish. Aquat. Sci. 43: 407-415.

Schelske C.L., Carrick H.J. and Aldridge F.J. 1995. Can wind-induced resuspension of meroplankton affect phytoplankton dynamics? J. N. Am. Benthol Soc. 14: 616-630.

Schelske C.L., Davis C.O. and Feldt L.E. 1984. Growth responses of river and lake phytoplankton populations in Lake Michigan water. Verh. Internat. Verein. Limnol. 22: 445-451.

Schwab D.J., Beletsky D. and Lou J. 2000. The 1998 coastal turbidity plume in Lake Michigan. Estuar. Coast Shelf. Sci. 50: 49-58.

Sicko-Goad L., Stoermer E.F. and Fahnenstiel G.L. 1986. Rejuvenation of Melosira granulata (Bacillariophyceae) resting cells from the anoxic sediments of Douglas Lake, Michigan. I. Light microscopy and 14C uptake. J. Phycol. 22: 22-28.

Sicko-Goad L., Stoermer E.F. and Kociolek J.P. 1989. Diatom resting cell rejuvenation and formation: time course, species records and distribution. J. Plankton Res. 11: 375-389.

Smetacek V.S. 1985. Role of sinking in diatom life-history cycles: Ecological, evolutionary, and geological significance. Mar. Biol. 84: 239-251.

Stoermer E. 1968. Nearshore phytoplankton populations in the Grand Haven, Michigan vicinity during thermal bar conditions. In: Proc 11th Conf. Great Lakes Res. Internat. Assoc. Great Lakes Res., pp. 137-150.

Stoermer E.F. and Ladewski T.B. 1976. Apparent optimal temperatures for the occurrence of some common phytoplankton species in southern Lake Michigan, Great Lakes Res Div. Pub. 18. University of Michigan, Ann Arbor, Michigan, USA.

Tester P.A., Geesey M.R., Guo C., Paerl H.W. and Millie D.F 1995. Evaluating phytoplankton dynamics in the Newport River Estuary (North Carolina, USA.) by HPLC-derived pigment profiles. Mar. Ecol. Prog. Ser. 124: 237-45.

US Environmental Protection Agency and Government of Canada 1995. The Great Lakes: An Environmental Atlas and Resource Book. 3rd ed. Environment Canada, Toronto, Canada.

Utermohl H. 1958. Zur Vervolkommung der quantitativen phytoplankton. Mitt. Int. Verein. Limnol. 9: 1-13.

Vollenweider R.A. 1974. A manual on methods for measuring primary production in aquatic environments, 2 nd ed. IBP Handbook No. 12. Blackwell Scientific, Oxford, UK.

Wetzel R.G. 2001. Limnology: Lake and River Ecosystems, 3rd ed. Academic Press, San Diego, California, USA. 